\title{
The Role of Organizational Support in Improving Employees Performance
}

\author{
Azzam Abou-Moghli ${ }^{1}$ \\ ${ }^{1}$ Department of Business Administration, Applied Science Private University, Amman, Jordan \\ Correspondence: Azzam Abou-Moghli, Department of Business Administration, Applied Science Private \\ University, Amman, Jordan. E-mail: a_aboumoghli@asu.edu.jo
}

Received: December 15, 2014

Accepted: January 4, 2015

Online Published: January 25, 2015

doi:10.5539/ibr.v8n2p198

URL: http://dx.doi.org/10.5539/ibr.v8n2p198

\begin{abstract}
The purpose of this study is to examine the role of organizational support through its dimensions: (organizational equity, leader's behavior supporting subordinates, and participation in decision making), in improving employees' performance. To achieve this purpose survey questionnaire was developed based on the related literature, and distributed to 175 employees working in researched Jordanian maritime transport companies. The statistical package for social science (SPSS) for windows was utilized to analyze the results. The research revealed that there is statistical significant role at the level of (5\%) for organizational support in improving employees' performance. Furthermore, the research recommended that working managers in Jordanian maritime transport companies to reinforce their abilities to train and educate the employees on the participation in decision making.
\end{abstract}

Keywords: employees performance, maritime transport companies, organizational support

\section{Introduction}

The contemporary business world is most characterized by the transformation and change speed in the business environment, which became the hallmark of this world. This resulted in fierce competition among the organizations' endeavors to acquire competitive advantage; and increase in the invention and technological changes rates. In addition, the emergence of the time-based competition put the business organizations in the face of showdowns with the challenges of survival, continuity and growth which basically depend on gaining excellence in providing services and products that enable them achieve the excellence. Furthermore, doing so provides the opportunity to integrate with the international economy, and enjoy high flexibility enabling these organizations adapt to these changes. As such, the organization that does not carry out internal changes to face the external changes is at the risk of failure. In this concern, the successful management is the creative management in finding solutions to the problems arising from the changing environment factors, through which it may make success. One of the important ways of any organization success is the existence of employees who are capable to put on the required effort to carry out all the work activities inside the organizations. And, in order that the organizations guarantee their best employees' performance, an organizational support becomes a must, being the basic motivator of energies and abilities. In the first place, it effects the human resources performance, and realizes high productivity levels through them. Accordingly, the current study aims at examining the role of organizational support in improving employees' performance.

\section{Literature Review}

\subsection{Organizational Support}

Organizational support (OS), based on organizational support theory, refers to the extent to which employees deem that their organization values their contribution and cares about their well-being (Eisenberger et al., 1986; Rhoades \& Eisenberger, 2002). OS can generate a felt obligation to care about the organization's welfare and to help the organization accomplish its goal (Eisenberger et al., 2001). In the meantime, OS should realize socioemotional needs by integrating organizational membership and role status into their social identity and reinforce employees' beliefs that organization financial and non-financial compensations increase performance (Rhoades \& Eisenberger, 2002). Employers want employees to be dedicated and loyal to their job. According to the norm of reciprocity, if employers offer a high level of support to their employees, employees are possibly to emotionally commit to their organizations with a low possibility of turnover and a high level of job performance 
(Allen et al., 2013; Hui et al., 2007; Miao, 2011). Previous empirical studies support that organizational support was related to job performance. The study of Manyasi et al., (2011) indicated that organizational support positively affect improving employees performance. (Manyasi et al., 2011). In a meta-analysis of 70 studies, Rhoades et al. demonstrated that employees' OS could increase job performance (Rhoades \& Eisenberger, 2002). Conversely, some previous studies have indicated contradictory findings. Stamper et al. reported that OS was unrelated to task performance among sales people (Stamper et al., 2011). Therefore, it is not clear whether OS is directly related to job performance. This study, investigate the role of organizational support in improving employees' performance specifically in Jordanian maritime transport companies. And here below a brief discussion of each dimension of OS variable analyzed in this study.

\subsubsection{Organizational Equity}

Researchers in the social and human sciences realized long ago, the importance of equity values and principles play inside the organization. Nevertheless, the term "organizational equity" did not appear until 1987 (Greenberg, 1987), referring to the employees' perception of equity and integrity in the organizations. Greenberg described the organizational equity as being the first virtue of the social organizations and institutions. Social equity focuses on the functional conditions that make the employees believe that they are fairly treated, or are subject to injustice and inequity (Folger \& Cropanzano, 1998).

Nadiri and Tanova, (2010) indicated that the organizational equity is the fairness by individuals for exchanges (inputs and outputs) that arise from the prevailing relations in the organization, which guarantees the relationship of the individual with the his/her supervisors, employees and colleagues of the same job rank; and his/her relationship with the organization as a social system. They further stated that the organizational equity is the individual's feeling of justice within the organization, and the behavioral reaction to this feeling. Elovainio et al. (2005) addressed the organizational equity and stated that it is the degree of the employees' feelings of the treatment they receive fairly and justly. Furthermore, organizational equity is concerned in task distribution, services, opportunities, rewards, punishments and wages (Noruzy et al., 2011).

\subsubsection{Leaders' Behavior for Supporting the Subordinates}

The effective leadership as viewed by many is the core thing for the success of any organization. Leaders' behavior is influenced by many variables, both at the internal and external levels. Moreover, an unlimited group of factors form this leadership behavior. Many research works assured the need for focusing on fundamental issues, such as the influence processes that describe followers of the leaders (Lian, 2012). They further underscored that the effective leadership should have ability to utilize different tactics in influencing, and possess the skills needed for such influences. Therefore, leaders must maintain a sound leadership method to enhance their subordinates. In this concern, Lian (2012) indicated that if there is no relevant leadership style exists, this will lead to negative outcomes of the subordinates, due to the misunderstanding and sensitivity, which will, in turn, result in dysfunction, such as low work performance, high absenteeism rates, higher rates of employees turnover.

Specialists studied the administrative leadership from behavioral perspective; or in a more accurate paraphrasing: How does the leader behave during his/her dealing with the subordinates? This orientation created a critical turning point in the development of the leadership behavior theories, and considered that the best method to judge the leader, instead of depending on his/her characteristics, is that these theories focus on the manner through which the leader deals with the subordinates. The assumption these theories build on is that the leader's behavior is always effective and influencing throughout all the circumstances and conditions. There is a reciprocal relationship between the manager and his/her employees, and every individual, according to this conception, provides to the other party something seen as valuable. Every party should consider the reciprocation process as a fair process so that this relationship will continue. In addition, a good relationship of the individual with his/her supervisor leads to the increase of the job satisfaction and employees' performance levels (Maslyn \& Uhl-Bien, 2001).

\subsubsection{Participation in Decision Making}

Participation in decision making means that the employees participate the managers in dealing with the information, decision making and problem solving. There is a participation in power practice between the owners and managers of the organizations and their employees (Muindi, F., 2011). The participatory style is quite contrary to the authoritarian styles in management. The participatory style looks at the employees according to their works as a whole, not merely as carrying out the instructions issued by the higher levels of the administrative hierarchy in the organization. This style provides the positive institutional climate that moves toward stimulating the creative energies of the employees. The participatory management is the interaction of the 
individual, both mentally and emotionally, with the group he/she works with, in a manner that enables him/her mobilize his/her efforts and energies to achieve the organization objectives and consciously accept its responsibility toward this individual. (Keith Davis, 1966).

\subsection{Employees' Performance}

performance is the ultimate result of the activity (Wheelen \& Hunger, 2002, p. 24); meanwhile Porter and his colleague Lowed see that the performance of the employees depends not only on the amount of effort spent, but also on the employees' abilities and skills, as well as their perception of the role that should be carried out (Porter $\&$ Lowed). Furthermore, the performance process management is a continuous communication process between the employee and his/her supervisor, and aims at communication to achieve a clear understanding of the works to be accomplished. The employees' performance is measured by comparing the actual results achieved by this ability for all the setout programs and objective strategy, in addition to defining the biases whether positive or negative, and then eliminating them (Bakal, 1999, p. 26).

\section{Methodology of the Study}

This study is concerned with the role of organizational support in improving employees' performance. The descriptive analytical method was implemented, since it is the most appropriate one for this study. The study population consisted of (148) maritime transport companies operating in Jordan. (175) questionnaires were distributed as a random sample of the population, the respondent were the non-managerial level employees. Only (130) questionnaires returned, this mean that approximately (74\%) from total distributed questionnaires were processed for statistical analysis.

The constructed questionnaire was adapted, based on the previous literature and studies (Krishnan \& Mary, 2012; Durrani et al., 2011; Eisenberger et al., 2002; Niehof \& Moorman, 1993; Williams \& Anderson, 1991). The questionnaire came into three parts: demographic variables, variable related to the organizational support, through three dimensions (organizational equity, Leader's behavior supporting the subordinates, and participation in decision making); as well as the variable concerning the employees' performance. The response range is (1-5) as per Lickert's five-point scale ranging from strongly disagree to strongly agree.

\subsection{Validity and Reliability of the Study Instrument}

The apparent validity of the questionnaire items was assured, by presenting them to a number of academic reviewers in universities of Jordan, who were requested to assign their view about the accuracy of the items of the study instrument and carrying out any relevant modification that serve the study. Their comments, suggestions and notes were taken into consideration; and, only items with $80 \%$ and more approval rates by the academic reviewers were adopted by the researcher. The reliability of the instrument was further verified through finding out the internal consistency coefficient of the questionnaire dimensions using Chronbach alpha equation. The following Table 1 exhibits that coefficients of reliability for all items were above the cut-off point of $70 \%$ used in the current study (Hair et al., 2006).

Table 1. Cronbach's alpha reliability coefficient of the study variables

\begin{tabular}{lcc}
\hline Variables & Number of Items & Chronbach's alpha \\
\hline Organizational Equity & 11 & 0.89 \\
Leadership Behavior & 9 & 0.87 \\
Participation in Decision Making & 6 & 0.79 \\
Employees Performance & 10 & 0.90 \\
\hline
\end{tabular}

\subsection{Hypotheses Testing}

The statistical package for social science (SPSS) for windows was utilized for performing the hypotheses testing. A regression analysis was run to test if there is a statistical significant role of three dimensions of organizational support (organizational equity, leader's behavior supporting subordinates, and participation in decision making), the independent variables (IV) in improving employees performance, the dependent variables (DV). See Tables (2-3) for the results.

\subsubsection{Main Hypothesis}

(H01): There is no statistical significant role of the organizational support through its dimensions: 
(organizational equity, leader's behavior supporting the subordinates, and participation in decision making) in improving employees' performance.

Table 2. Results of regression analysis among organizational support and employees' performance

\begin{tabular}{cccc}
\hline $\mathrm{R}$ & $\mathrm{R}^{2}$ & Adjusted $\mathrm{R}^{2}$ & $\mathrm{Sig}$ \\
\hline 0.738 & 0.487 & 0.384 & 0.000 \\
\hline
\end{tabular}

Note. Significant if $\alpha \leq 0.05$.

Table 2 illustrates that the correlation coefficient between the organizational support and the improvement of the employees' performance was (0.738), which is a high value, indicative of a direct positive relationship. The value of the determination coefficient $\left(\mathrm{R}^{2}\right)$ amounted $(48.7 \%)$, indicating that the organizational support with its dimensions is interpreted by the change or variance occurring in the employees' performance improvement, equivalent to the said rates. Furthermore, adjusted $\left(\mathrm{R}^{2}\right)$ value could be used, which takes into consideration the number of the independent variables, so that adjusted determination percentage accounts for $(38.4 \%)$, which is less than the typical $\left(\mathrm{R}^{2}\right)$ value, which could be ascribed to the number of the independent variables. The remaining amount of any of the percentages/rates is due or related to other factors, which may have a role in improving employees' performance.

\subsubsection{Sub Hypotheses Testing}

H01: There is no statistical significant role of the organizational equity in improving employees 'performance.

Table 3. Results of regression analysis among the dimensions of organizational support and employees' performance

\begin{tabular}{|c|c|c|c|c|c|}
\hline \multirow{2}{*}{ Model } & \multicolumn{2}{|c|}{ Unstandardized Coefficients } & \multirow{2}{*}{$\begin{array}{c}\text { Standardized Coefficients } \\
\text { B }\end{array}$} & \multirow{2}{*}{$\mathrm{T}$} & \multirow{2}{*}{$\operatorname{Sig}(t)$} \\
\hline & $\beta$ & Std error & & & \\
\hline Constant & 0.898 & 0.428 & - & 2.991 & 0.004 \\
\hline Organizational Equity & 0.107 & 0.059 & 0.120 & 3.229 & 0.803 \\
\hline Leaders' Behavior & 0.096 & 0.053 & 0.187 & 2.048 & 0.047 \\
\hline Participation in Decision Making & 0.365 & 0.051 & 0.529 & 7.281 & 0.000 \\
\hline
\end{tabular}

Note. Significant if $\alpha \leq 0.05$.

Table 3 explains that calculated (t) value amounted (3.229) with (0.803) significance when compared with the (0.05) significance level. This indicates the denial of the first null sub-hypothesis of the study, and subsequently, it is concluded that there is a role of the organizational support through organizational equity on the improvement of the employees' performance in the Jordanian maritime transport companies. Table 3 further shows that the amount of $(\beta)$ coefficient $(0.107)$ is a value showing the increase in the organizational equity, when the value of the improvement of the employees' performance is increased by one unit.

H02: There is no statistical significant role of the leaders' behavior supporting the subordinates in improving employees' performance.

Table 3 shows that calculated (T) value amounted (2.048) with (0.047) significance level. And, when the significance level value is compared with the value $(0.05)$, it is found that the calculated significance level was higher than (0.05), which indicates the acceptance of the second, alternative sub-hypotheses. Therefore, it is concluded that there is a role of the organizational support, through the leaders' behavior toward their subordinates, in improving employees' performance in the Jordanian maritime transport companies. Table 3 further shows that the amount of $(\beta)$ coefficient $(0.096)$ is a value showing the increase in the leaders' behavior supporting the subordinates, when the value of the improvement of the employees' performance is increased by one unit.

H03: There is no statistical significant role of the participation in decision making in improving employees performance.

Table 3 shows that calculated (T) value amounted (7.281) with (0.000) significance level. And, when the 
significance level value is compared with the value (0.05), it is found that the calculated significance level was higher than (0.05), which indicates the acceptance of the third, alternative sub-hypotheses. Therefore, it is concluded that there is a role of the organizational support through participation of the employees in the decision making on the improvement of the employees' performance in the Jordanian maritime transport companies. Table 3 further shows that the amount of $(\beta)$ coefficient $(0.365)$ is a value showing the increase in the employees' participation in the decision making when the value of the improvement of the employees' performance is increased by one unit.

\section{Results}

The results of the study demonstrated a statistical significant role of the organizational support through its dimensions: (organizational equity, leader's behavior supporting the subordinates, and participation in decision making), in improving employees' performance in the Jordanian maritime transport companies at $(\alpha \leq 0.05)$ level. This result is in line with the study of Chinomona (2011), which indicated that there is a positive relationship of the role of the organizational support on the spirituality of the work and the employees' performance. This current study is also in agreement with that of Yu (2011), which indicated that the organizational support has an effect on the success and job satisfaction. Furthermore, the results of the current study can assist managers to discover ways to employ OS dimensions to improve employees' performance in their organizations.

\section{Recommendations and Future Research}

In the light of these results, the researcher recommends the following:

Reinforcing the abilities of the managers in the Jordanian maritime transport companies through enabling and encouraging them to train and educate the employees on the participation in decision making. And developing the potentials of the managers in the Jordanian maritime transport companies for the aim of improving the employees' response mechanisms to the contemporary developments and changes in the business environment. Finally, further studies could be conducted investigating the potential role of some mediating variables such as job satisfaction or organizational commitment.

\section{Acknowledgment}

The author is grateful to the Applied Science Private University, Amman, Jordan, for the full financial support granted to this research project (Grant No. DRGS-2014-2015).

\section{References}

Allen, D. G., Shore, L. M., \& Griffeth, R. W. (2003). The role of perceived organizational support and supportive human resource practices in the turnover process. J. Manag., 29(1), 99-118. http://dx.doi.org/10.1177/014920630302900107

Chinomona \& Richard. (2012). The impact of organizational support on work spirituality, organizational citizenship behavior and job performance: The case of Zimbabwe's small and medium enterprises (SME) sector. African Journal of Business Management, 6(36), 10003-10014. http://dx.doi.org/10.5897/AJBM11.2286

Durrani, B., Ullah, O., \& Ullah, S. (2011). Effect of leadership on employees performance in multinational pharmaceutical companies in Pakistan. Journal of Contemporary Research in Business, 2(9). http://dx.doi.org/10.1016/j.ijpe.2009.08.026

Eisenberger, R., Armeli, S., Rexwinkel, B., Lynch, P. D., \& Rhoades, L. (2001). Reciprocation of perceived organizational support. J. Appl. Psychol., 86(1), 42. http://dx.doi.org/10.1037//0021-9010.86.142

Eisenberger, R., Huntington, R., Hutchison, S., \& Sowa, D. (1986). Perceived organizational support. J. Appl. Psychol., 71(3), 500-507. http://dx.doi.org/10.1037/0021-9010.71.3.500

Elovainio, M., Van den Bos, K., Linna, A., Kivimaki, M., Ala-Mursula, L., Pentti, J., \& Vahtera, J. (2005). Combined effects of uncertainty and organizational justice on employee health: Testing the uncertainty management model of fairness judgments among Finnish public sector employees. Social Science and Medicine, 61(12), 2501-2512. http://dx.doi.org/10.1016/j.socscimed.2005.04.046

Folger, R., \& Cropanzano, R. (1998). Organisational justice and human resource management. California, Thousand Oaks: Sage Publications.

Gardner, W. L., \& Schermerhorn, J. R. Jr. (2004). Unleashing individual potential: Performance gains through positive organizational behavior and authentic leadership. Organizational Dynamics, 33, 270-281. http://dx.doi.org/10.1016/j.orgdyn.2004.06.004 
Greenberg, J., \& Baron, R. A. (2008). Behaviors in organization. Dorling Kindersley (India) Pvt .Ltd.

Hair, J., Black, W., Babin, B., Anderson, R., \& Tatham, R. (2006). Multivariate data analysis (6th ed.). Pearson Prentice Hall.

Hui, C., Wong, A., \& Tjosvold, D. (2007), Turnover intention and performance in China: The role of positive affectivity, chinese values, perceived organizational support and constructive controversy. J. Occup. Organ. Psychol., 80(4), 735-751. http://dx.doi.org/10.1348/096317906X171037

Keith, D. (1966). Human relation at work (2nd ed.). Kogakusha co. 1td, Tokyo.

Krejcie, R. V., \& Morgan, D. W. (1970). Determining sample size for research activities. Educational and Psychological Measurement, 30, 607-610. http://dx.doi.org/10.1177/001316447003000308.

Krishnan, J., \& Mary, S. (2012). Perceived organization support: An overview on its antecedents and consequences. International Journal of Multidisciplinary Research, 2(4), 1-2.

Lian, L. K. (2012). Leadership styles and organizational citizenship behavior: The mediating effect of subordinates competence and downward influence tactics. Journal of Applied Business and Economics, 13(2), 59-96.

Manyasi, J., Kibas, P. B., \& Chep, K. R. (2011). Effects of organizational support for career development on employee performance: A case of Kenyan public universities. Kabarak University First International Conference (pp. 1-17).

Maslyn, J., \& Mary, U. B. (2001). Leader- member exchange and its dimensions: Effects of self-effort and other's effort relationship quality. Journal of Applied Psychology, 86(4), 697-708. http://dx.doi.org/10.1037/0021-9010.86.4.697

Miao, R. T. (2011). Job satisfaction, task performance and organizational citizenship behavior in China. J. Behav. Appl. Manag., 12(2), 105-127. http://dx.doi.org/10.1186/1472-6920-14-50

Muindi, F. (2011). The Relationship between participation in decision making and job satisfaction among academic staff in the school of business, University of Nairobi. Journal of Human Resources Management Research, 20, 9-34. http://dx.doi.org/10.5171/2011.246460

Nadiri, H., \& Tanova, C. (2010). An investigation of the role of justice in turnover intentions, job satisfaction, and organizational citizenship behavior in hospitality industry. International Journal of Hospitality Management, 29, 33-41. http://dx.doi.org/10.1016/j.ijhm.2009.05.001

Niehoff, B., \& Moorman, R. (1993). Justice as a mediator of the relationship between methods of monitoring and organizational citizenship behavior. Academy of Management Journal, 36(3), 527-556. http://dx.doi.org/10.2307/256591

Noruzy et al. (2011). Investigation the relationship between organizational justice, and organizational citizenship behavior: The mediating role of perceived organizational support. Indian Journal of Science and Technology, 4(7), 842-847.

Rhoades, L., \& Eisenberger, R. (2002). Perceived organizational support: A review of the literature. J. Appl. Psychol., 87(4), 698. http://dx.doi.org/10.1037//0021-9010.87.4.698

Stamper, C. L., \& Johlke, M. C. (2003). The impact of perceived organizational support on the relationship between boundary spanner role stress and work outcome. J. Manag., 29(4), 569-588. http://dx.doi.org/10.1016/S0149-2063_03_00025-4

Williams, L. J., \& Anderson, S. E. (1991). Job satisfaction and organizational commitment as predictors of organizational citizenship and in-role behaviors. J. Manag., 17(3), 601-617. http://dx.doi.org/10.1177/014920639101700305

\section{Copyrights}

Copyright for this article is retained by the author(s), with first publication rights granted to the journal.

This is an open-access article distributed under the terms and conditions of the Creative Commons Attribution license (http://creativecommons.org/licenses/by/3.0/). 